\title{
GEOLOGY
}

UDC 550.83

E. D. Kuzmenko, Dr. Sc. (Geol.-Min.), Prof., orcid.org/0000-0002-1994-0970,

I. V. Chepurnyi, Cand. Sc. (Geol.), Assoc. Prof., orcid.org/0000-0003-2109-3827,

T. B. Chepurna, Cand. Sc. (Geol.), Assoc. Prof., orcid.org/0000-0002-1140-4356,

S. M. Bagriy, Cand. Sc. (Geol.), Assoc. Prof., orcid.org/0000-0003-1190-6222

\section{SUBSIDENCE AND FAILURES WITHIN THE TERRITORY OF PRECARPATHIAN SALT FIELDS AND THE POSSIBILITY OF THEIR PREDICTION}

Purpose. To show the effectiveness of application of method of natural pulsed electromagnetic field of the Earth (NPEMFE) in issues of spatial prediction of the earth's surface deformation, for assessing the karst hazard within territories with exhausted salt deposits. Improvement of existing methods of interpretation of data obtained as a result of applying of NPEMFE by involving geodetic information.

Methodology. Processing the information obtained as a result of measurements of the NPEMFE with the help of GIS-technologies. Spatial combination of data interpretation results obtained through the NPEMFE method with results of geodetic observations.

Findings. The image of the spatial combining of NPEMFE intensity maps and the earth surface subsidence is constructed. The hypothesis that the anomalies of NPEMFE are a direct indicator of displacement of the earth's surface is proved.

Originality. For the first time, on the example of the territory of the Stebnyk potassium salt mining field, the results of topogeodetic survey and those of the geophysical method of NPEMFE have been compared. Connection of geodetic and geophysical data and a significant level of their correlation is proved. This gives grounds for considering the NPEMFE method as a predictive in terms of forecasting the development of deformation processes of the earth's surface.

Practical value. The improvement of the method for interpreting the NPEMFE data by involving geodetic information is proposed.

Keywords: subsidence, failures, geophysical investigations, karst, salt deposit, displacement

Introduction. Natural-manmade subsidence and failures of the earth's surface within salt deposits areas are a consequence of activities of the mining enterprises that have extracted the rock and potassium salt. As a result, significant volumes of voids are formed, which leads to disturbances in the balance of rock massifs and the development of dangerous geological processes within the mining areas of enterprises and adjoining areas, which are accompanied by failures and subsidence of the earth's surface.

For the Carpathian region this refers to the Solotvyn rock salt deposit (Transcarpathia), Kalush-Holyn and Stebnyk deposits of potassium salt (Precarpathians). These deposits have been intensively exploited during the $19^{\text {th }}-21^{\text {st }}$ centuries. The facts of significant sediments and numerous collapses are evident at all of these deposits. In particular, 25 karst failures occurred in the Carpathian region on the Kalush-Holyn mining field, and the biggest of the subsidence was 07.06.87, the size $200 \times 180 \times 8.5 \mathrm{~m}$, the volume of $306000 \mathrm{~m}^{3}$.

29 failures were documented within Stebnyk deposit. The last significant event in this regard was recorded on September 30,2017 , when a sinkhole with a diameter of $220-230 \mathrm{~m}$ and a depth of 45-47 m was formed. The failures and surface subsid-

(C) Kuzmenko E. D., Chepurnyi I. V., Chepurna T. B., Bagriy S. M., 2020 ence are observed visually or with the help of geodetic measurements and indicate the fact that has already happened. The problem, however, is the development of a methodology for forecasting geological-nature emergencies, which are associated with natural and technogenic deformation processes on the surface of the earth's crust in the specific geological and hydrological conditions inherent to the territories with salt deposits mining.

Literature review. Failure phenomena on the territories of salt deposits mining have been and are still observed in different countries of the world. Examples can be given for Germany, Russia, Poland, and Ukraine. A comprehensive overview of these territories is given in the monograph [1]. Results of geodetic observations of the earth's surface deformation are usually stored at mining enterprises or scientific institutions. In particular, for Precarpathian salt deposits, this information is highlighted in separate publications [2, 3].

Recently, the results of vertical displacements monitoring with the use of satellite interferometric radar measurements [4] have appeared. As for the prediction of subsidence and failures it is expedient to consider two main directions, which to some extent complement each other. The first direction is the creation of calculation models with the involvement of geological, hydrogeological information, direct observations on the situation on mining areas and physical modeling data. This 
is demonstrated, first of all, in the works by specialists of LLC "Hirkhimprom" (Lviv) [1, 3, 5]. At the same time, we should note publications with detailed coverage of certain aspects of the problem, such as hydrogeological one [5]. The paper [6] states that this approach allowed predicting the failure (that occurred in 2017) in 2007, the forecast was finally clarified in 2014. It should be noted that this failure was the cause of the technogenic earthquake with a magnitude $M=2.9$ on the Richter scale [7].

Therefore, as the second direction we should consider a complex of geophysical methods. Geophysical investigations at different times were carried out by the West-Ukrainian Geophysical Exploration Expedition (Lviv), State Enterprise Spetsheolohorozvidka (Ivano-Frankivsk), State Enterprise "Ukrainian Geological Company" (Kyiv), Carpathian region Department of the Institute of Geophysics of the National Academy of Sciences of Ukraine (Lviv), Ivano-Frankivsk National Technical University of Oil and Gas (Ivano-Frankivsk). The results are concentrated in reports and are highlighted in next publications $[8,9]$.

The proposed complex of geophysical methods is quite limited in their number: gravimetry, sounding by the method of electromagnetic induction logging, vertical electrical sounding, the method of the natural pulsed electromagnetic field of the Earth (NPEMFE).

The first three methods are common in the practice of geological exploration and have a thoroughly developed technical, methodological and interferential background [10]. Regarding the NPEMFE, strangely enough, this method is still limited in spreading and has not been used outside of Russia, Ukraine, and China [11, 12]. Scope of its application involves solving engineering and geological problems.

Purpose. The purpose of this article is to prove the effectiveness of the NPEMFE method with the plane prediction of the deformation of the earth's surface and to assess the karst hazard in exhausted salt deposits as well as to improve the method for interpreting data by involving geodetic measurements in the analysis.

As a research object, Stebnyk potassium salt deposit, which is located in Lviv region, is considered. The research site is located in the Inner zone of the Precarpathian Deflection. The deposits forming the geological structure of the territory belong to the lower Neogene.

Methods. The basis of the NPEMFE method is the relation of the intensity of the natural pulsed electromagnetic field to changes in the stress-strain state of rocks. The geological preconditions of the method are given forth in the writings of Vorobyov and Solomatin.

In the Stebnyk mine area, the rocks are represented by flush-like alternating of sandstones, siltstones, argillites and clays. These deposits contain industrial deposits of explored potassium salts, which lie at depths from hundred to five hundred meters. Above the salted rocks the gypsum clay weathering crust was formed.

Extraction of salt was carried out by the chamber method. The chambers were located on four horizons - at different depths - from 100 to $400 \mathrm{~m}$ (depending on the geological section).

During operation in mines there were repeated breakthroughs of formation water in the extraction chambers. This led to a misbalance of the natural hydrogeological balance, the intensification of the filtration of surface water into salt layers, the breakage of salt fractions and the weakening of the stability of the rock massif. According to various estimates, 2.5-3 million $\mathrm{m}^{3}$ of technogenic voids were formed due to the dissolution of salt, that is, in the process of karst formation.

Along with the presence of mining chambers and their destruction, as a result of the erosion of protective pillars, the formation of karst cavities has led to significant depressions and drops on the surface. It is obvious that the territory of mine No. 2, where there is a self-flooding or artificial flooding with undersaturated brines, has bigger karst hazard.

The research area presented in this publication is located in the western part of mine No. 2. This territory includes a fragment of the "Skhidnytsia-Pisochne" highway, which is the main highway to the famous resort of Truskavets. The deformation of the roadbed is the cause of the survey of this particular place. Methods of research: geodetic surveying and geophysical method of natural pulsed electromagnetic field of the Earth. In contrast to the above-mentioned publications, the presented article provides a thorough analysis of the dynamics of subsidence over a specified period of time and a quantitative statistical estimate of the relationship of subsidence with the data of the NPEMFE, which allows not only stating the fact of the hazardous situation of the geological environment, but also making predictive conclusions about the development of this situation.

Geodetic monitoring of the subsidence of the earth's surface is carried out within the territory of Stebnyk deposit by 24 geodetic profiles since 1987.

At present, most of the points of these profiles have been saved. Observations were carried out by the geodetic service of PJSC "Polimineral".

The authors created a database of the results of observations with the aim to assess the dynamics of the earth's surface subsidence by the data of geodetic observations. Altogether 544 reference points were processed.

Results. Along the "Skhidnytsia-Pisochne" road, through the survey area of the NPEMFE from the south to the north, geodetic reference line No. 12 passes.

Output data for analyzing the size and dynamics of subsidence are presented in Fig. 1. The graph of the values of altitude of reference points for line number 12 over 1996 and 2017 is shown in Fig. 1, $a$. The figure shows that the reference line 12 was installed in 1996, it contains 57 points. The graphs of interval subsidence are then depicted with discretes in 5 years (Fig. 1, b) and graphs of accumulated subsidence from 5 to 20 years (Fig. 1, $c$ ).

The analysis of the graphs shows the following. From 57 reference points, 20 subsided by more than $30 \mathrm{~cm}, 10$ points - by more than $50 \mathrm{~cm}$, and 4 points changed their location by more than 1 meter. This is confirmed by the graphs of accumulation of subsidence. The annual amount of subsidence is best visualized by Fig. $1, d$. From the figure it is clear that activation took place in 1999, then in 2002-2004, 2007-2017. Annual activation in 1999 was insignificant in absolute terms, but occurred throughout the reference line. This is probably due to the intense precipitation of 1998-1999, which caused the activation of all exogenous geological processes. The next activation again throughout the reference line occurred in the interval 2002-2004, while the subsidence increased from north to south, reaching a maximum in today's swampy lowland.

It was in those years that the artificial reservoir, which stretches near highway from south to north in parallel with it, was filled and now is a water supplier in this relief lowering. As seen from the graphs and charts, in the area of points $654-667$ subsidence has been developing in subsequent years. According to the accumulation chart, this subsidence reached a maximum near point 665 at $1760 \mathrm{~mm}$.

Subsided area is a place of intense infiltration with subsequent movement of water in the direction of the depression to the north - north-east. Subsidence is probably associated with the dissolution of salts and suffusion. An additional factor, which contributes to intense infiltration, is the presence of stratigraphic contact that is the zone of weakening of the strength of rocks. The roadbed in front of the anomalous area is deformed.

Subsidence along reference line No. 12 over 2007-2017 was not uniform. We described and explained one anomaly centered near point 665 from the physical point of view. An- 


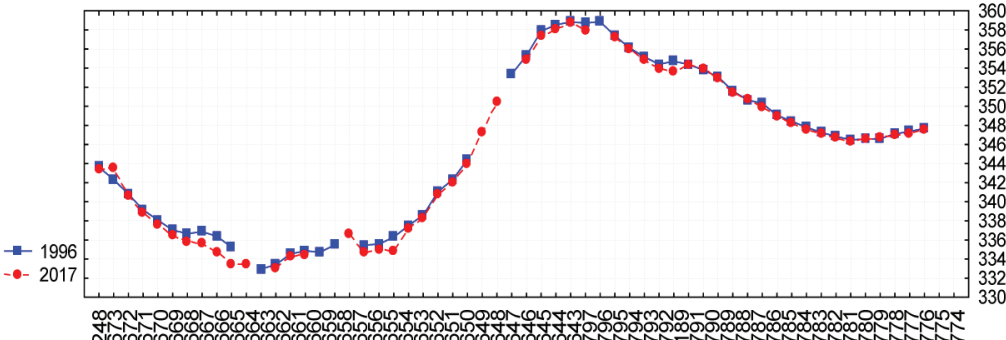

$a$

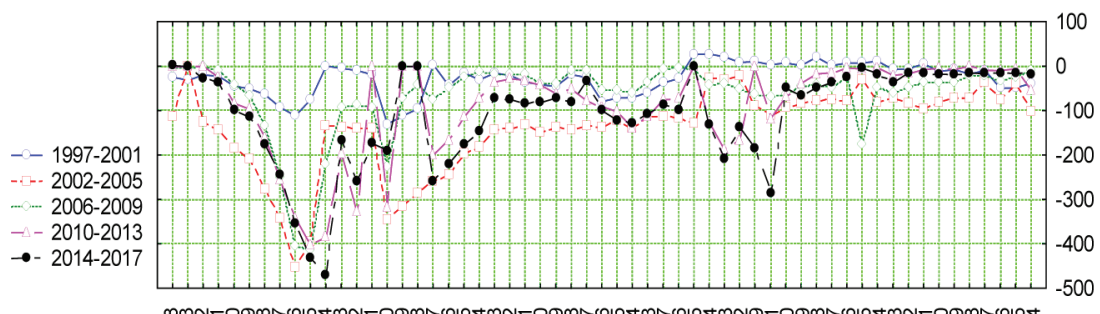

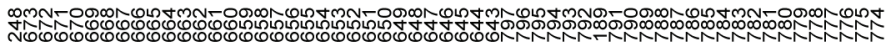

$b$
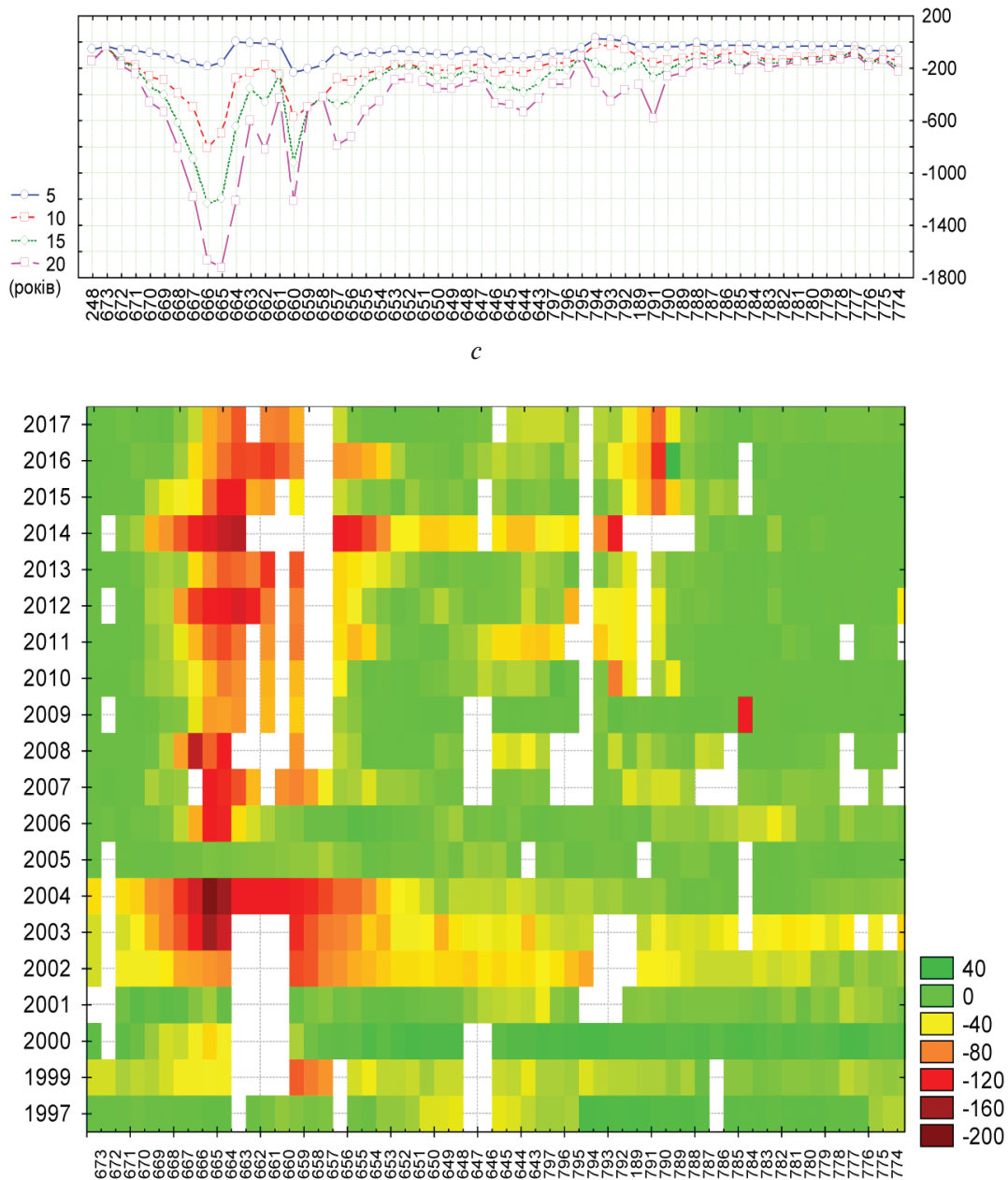

Fig. 1. Dynamics of displacement on reference line No. 12:

$a$ - graph of absolute heights of reference points; $b$ - graph of interval subsidence; $c$ - graph of accumulated subsidence; $d-d i a g r a m$ of annual subsidence

other significant subsidence was activated in 2010 and evolved with increasing speed, especially over 2015-2017. This is an area near 790-792 points with a total subsidence of picket 791 (for the entire observation period) $-585 \mathrm{~mm}$, including that over 2014-2017 years - $286 \mathrm{~mm}$. From a geological point of view, the area of subsidence belongs to the southern part of the ensemble of mining chambers in salt layers. It should be noted that the area of subsidence belongs to the place of roadbed deformation.

The results of topogeodetic observations allow de facto establishing zones of near-surface deformations of the earth's surface, related to its subsidence. The question is the follow- 
ing - will these areas continue to subside? This question should be answered by the NPEMFE method.

The research by the NPEMFE method was performed along the road at a distance of $150 \times 1200 \mathrm{~m}$, by the grid $10 \times$ $\times 20 \mathrm{~m}$ in the $2-50 \mathrm{kHz}$ frequency range. This made it possible to trace in a section places with tensely deformed state at a depth of $350 \mathrm{~m}$ from the surface, which is the depth of laying of the extraction chambers. The fieldwork was performed in 2016 and 2017 with the aim to track the dynamic of deformation development in a rock massif. The work was carried out using a radio-wave indicator of stress-strain state (RWISSS) in accordance with the instruction.

The results of the interpretation of the NPEMFE data are maps of the intensity of the natural electromagnetic field along the antennas $X, Y, Z$, as well as maps of the full field intensity vector.

Physical side of the NPEMFE method and our experience of the work with it in terms of the development of natural technogenic karst $[1,11]$, suggest that the initial and active deformation stage causes an increase in the intensity of the electromagnetic field.

In this case, the major anomalies are inherent in the gradient zones. For the deformation damping stage, the further reduced field is characterized by the saving of positive values. At these stages, the field is heterogeneous with a significant differentiation in absolute values. This is exactly what NPEMFE intensity field at the indicated place in 2016 looked like.

The active stage of a stress-strain state passes into a stage of reduction or ends with a destructive stage (a stage of destructive deformations) with significant displacement of rocks, which are reflected on the earth's surface by a significant subsidence. Such areas are zones of discharge with the special reaction of the electromagnetic field in the form of significant abnormalities of the decrease in the intensity of the field.

It is quite logical that on the area of the presence of such anomalies there is a local subsidence - in this case, we should expect the development of subsidence within the entire anomaly.

This is the picture observed on the maps of intensity of the electromagnetic field according to the results of research in 2017.

For accurate assessment of the concordance of the data of the NPEMFE geophysical method and the results of topogeodetic observations for reference line No. 12, a graph with the field intensity of one of the antennas (antenna $X$ ) and the surface displacement in 2017 was constructed. The anomalies of decreasing of the intensity of the field and the subsidence of the earth's surface within the limits of the points 660-668 and 787-793 are expressive, with a maximum of annual subsidence, respectively, of $96 \mathrm{~mm}$ on 664 and $89 \mathrm{~mm}$ on point 791 . As for the first anomaly, its dimensions by geophysics and geodesy methods coincide. As for the second anomaly, the downfall in the relief is a part of the geophysical anomaly.

The results of the geophysical analysis for all 57 points of the reference line are presented in the form of cross-correlation diagrams for the displacement of the earth's surface and all variants of the observations of the field.

Correlation coefficients, as it should be on the physical content, are positive. Their values are low in absolute value $(r=0.19-0.3)$, but statistically significant.

This should be expected, because the area of anomalies of the NPEMFE in this case is larger than the area of subsidence. The fact is that using the NPEMFE method, traces of deformations that occur in rock massif underground and only eventually will be reflected through the subsidence on the surface.

In this sense, the method is predictable. This is confirmed by a map of results of the NPEMFE method, combined with the results of geodetic observations, which are conventionally depicted in the form of a broad profile (Figs. 2, 3).

From the figures it is clear that the NPEMFE method allows determining geometric areas of field anomalies with a

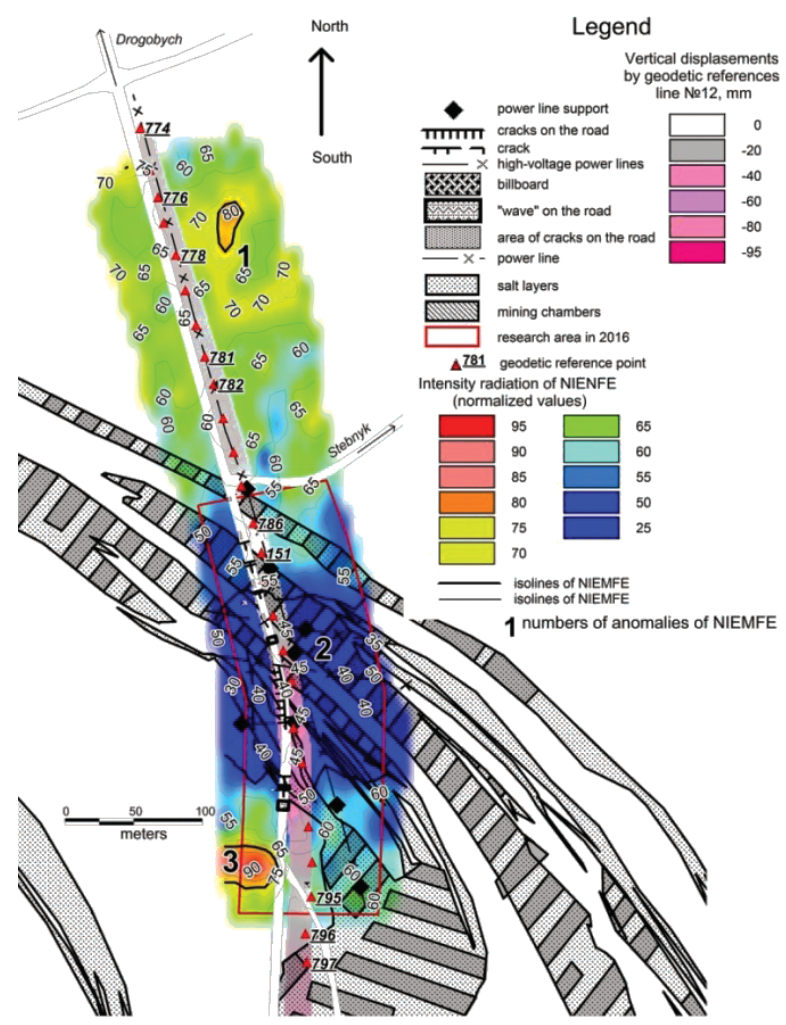

Fig. 2. Plane combining of maps of the NPEMFE intensity and the Earth surface subsidence in 2017 along reference line No. 12. Northern part of the research area

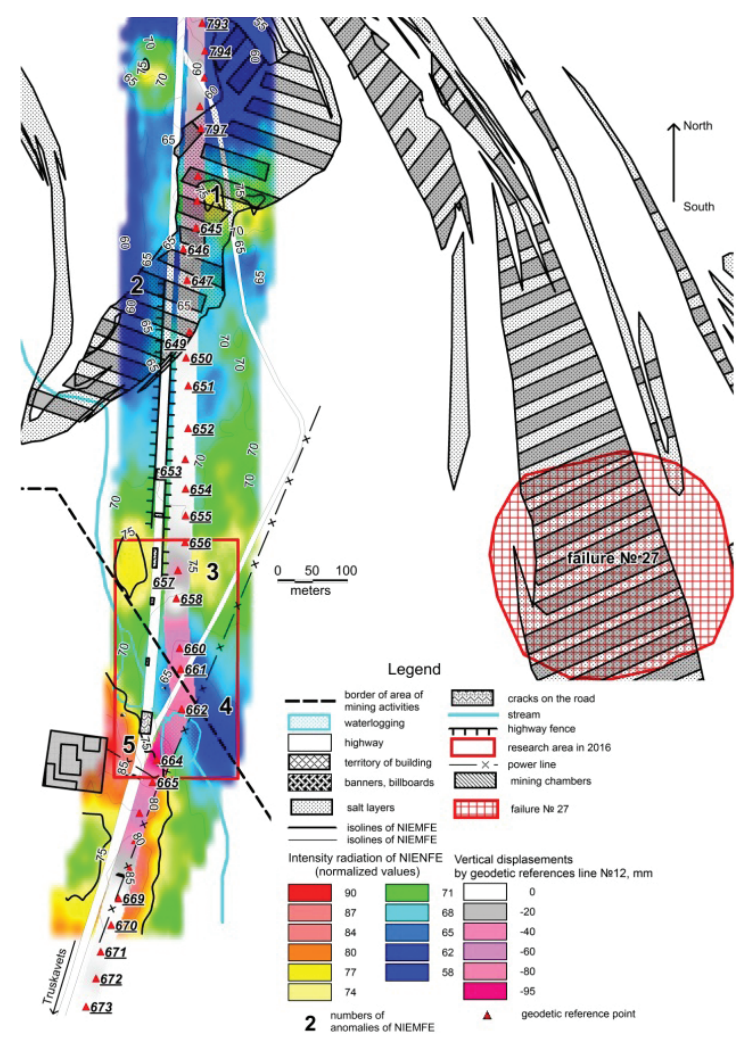

Fig. 3. Plane combining of maps of the NPEMFE intensity and the Earth surface subsidence in 2017 along reference line No. 12. Southern part of the research area

high degree of accuracy and considering them in the context of development of deformation in massifs of indigenous rocks. In this case, the NPEMFE anomalies are a direct indicator of the displacement of the earth's surface. 
Geodetic surveying is a compulsory component of the research complex, as it allows confirming the reliability of geophysical studies to establish the stage of development of deformation processes, and thus defining an approach to the interpretation of geophysical data, helping in determining the causes of deformation and determining the extent of their further development.

From Figs. 2, 3 it is possible to make conclusions on the further development of deformation processes throughout the area of mining chambers location within the territory of the geophysical survey. The contours of the future subsidence are clearly identified as anomalies contours of NPEMFE (blue colour in the figure). Probably this anomaly should be traced to south-east along the salt layers at least to a karst collapse (failure dated 30.09.17) indicated in the figure.

Conclusions.

1. One of the most important direction of study of territories with exhausted deposits of rock and potassium salt within the Carpathian region is the research on dangerous situations associated with deformation processes in the pre-surface part of rock massifs.

2. The only method of quantitative estimation of the earth's surface deformations within territories of mining fields of salt deposits is the topographic geodetic work.

3. Analysis of studies, related to the diagnosis of the state of a rock massif in the extraction zones, suggests that the reliable methods of non-destructive testing at the preliminary stage of the study are geophysical methods.

4. Among the geodetic methods at the stage of expert assessment of the strained-deformed state of rocks and the prediction of deformation processes development, it is necessary to distinguish the method of the natural pulsed electromagnetic field of the Earth.

5. The projection of planar anomalies of the NPEMFE in the analysis of their gradation by intensity allows specifying the stage of the earth's surface subsidence, including determining an area, when underground deformations of the rock masses already occur, but not yet reflected on the surface. In this sense, the method is predictable. Reliability of the interpretation of the NPEMFE data is achieved using the results of geodetic observations.

6. Further development of the use of the NPEMFE methodology is appropriate to link with the improvement of interpretation by creating spatial geological and geophysical models under the conditions of integration with geodetic observations and other geophysical research.

\section{References.}

1. Gaidin, A. M., \& Rudko, G. I. (2016). Technogenic karst. The state Ukrainian Commission on Mineral Resources: monograph. Kyiv; Chernivtsi: Bukrek.

2. Burak, K. O., Kuzmenko, E.D., Bagriy, S.M., Grinishak, M.Ya., Melnichenko, G.G., Mykhailyshyn, V.P., \& Kovtun, V. M. (2014). Features of geodetic monitoring and forecasting of geotechnical dynamics at mine fields of potassium deposits. Journal of Geodesy and Cartography, (5), 12-18. 3. Gaydin, A. M., Dyakov, V. O., \& Chikova, I. V. (2014). Deformations of the earth's surface in the area of activity of potassium mines in Stebnyk. Ecological safety and balanced resource use, (2), 112-119.

4. Mordvinov, I.S., Stasyuk, V.M., Pakshin, M.Yu., \& Lyask, I. I. (2018). Monitoring of vertical displacements of the territory of the "Polimineral" using satellite interferometric radar measurements. Subsoil use in Ukraine. Prospects for investment. Materials of the Fifth International Scientific and Practical Conference, 2 vol., October 8-12, 2018, (pp.94-102). Truskavets: State Commission of Ukraine for Mineral Resources (GKZ). Retrieved from http://conf.dkz.gov.ua/ files/2018 materials vol 2 net.pdf.

5. Pavlyuk,V. I. (2016). Natural factors of activation of exogenous processes on technogenically disturbed areas with salty deposits of Precarpathians. Geodynamics, 1(20), 94-105.
6. Dyakov, V. O., Dranovska, A.V., \& Hevpa, Z.Z. (2018). Failure of September 30, 2017, over mine No. 2 of Stebnyk's Polimineral: causes, consequences and current state (based on the results of material-balance modeling and monitoring observations). Subsoil use in Ukraine. prospects for investment. Materials of the Fifth International Scientific and Practical Conference, 2 vol., October 8-12, 2018, (pp. 103-115). Truskavets: State Commission of Ukraine for Mineral Resources (GKZ). Retrieved from http://conf.dkz.gov.ua/files/2018_materials vol 2 net.pdf.

7. Nazarevych, L. Y., Nazarevych, A. V., Nishchimenko, I. M., \& Oliynyk, H. I. (2018). The failed technogenic earthquake of september 30(29), 2017, in Stebnyk and the natural seimotectonic activity of the area. $17^{\text {th }}$ International Conference on Geoinformatics - Theoretical and Applied Aspects. https://doi. org/10.3997/2214-4609.201801821.

8. Shurovsky, O.D., Anikeev, S.G., Shamodko, V. I., \& Deshchitsa, S. A. (2013). Geophysical monitoring of the geological environment for the solution of environmental problems within the Kalush agglomeration. Mining Journal, (12), 99104.

9. Chepurnyi, I., Podholov, V., Kuzmenko, E., Chepurna, T., $\&$ Bagriy, S. (2018). Analysis of time factors of the karst processes development within areas of potassium salt deposits of precarpathians. $12^{\text {th }}$ International Scientific Conference \& amp; Quot; Monitoring of Geological Processes and Ecological Condition of the Environment\&amp; Quot. https://doi. org/10.3997/2214-4609.201803211.

10. Kuzmenko, E. D., Chupurna, T.B., Chepurnyi, I. V., Bagriy, S. M., Davybida, L. I., \& Shtogrin, L. V. (2018). Forecasting of subsidence of the earth's surface within the salt deposits areas of precarpathians by a complex of geophysical and geodetic studies. $17^{\text {th }}$ International Conference on Geoinformatics - Theoretical and Applied Aspects. https:// doi.org/10.3997/2214-4609.201801823.

11. Kuzmenko, E.D., Maksumchuk, V.Y., Bagriy, S.M., Sapuzhak, O. Y., Chepurnyi, I. V., \& Dzoba, U. O. (2018). On the relevance of using a complex combination of NIEMFE and EM methods in forecasting rock deformation. $17^{\text {th }}$ International Conference on Geoinformatics - Theoretical and Applied Aspects. https://doi.org/10.3997/2214-4609.201801820.

12. Malyshkov, S.Yu., Gordeyev, V.F., \& Polivach, V.I. (2017). Field studies of the dynamics of technogenic landslide. Geology and Geophysics of the South of Russia, (2), 80-90.

\section{Просідання та провали на території соляних родовищ Передкарпаття та можливість їх прогнозування}

\section{Е. Д. Кузьменко, І. В. Чепурний, Т. Б. Чепурна, С. М. Багрій}

Івано-Франківський національний технічний університет нафти і газу, м. Івано-Франківськ, Україна, email: tetti.chepurna@gmail.com

Мета. Показати ефективність застосування методу вимірювання природного імпульсного електромагнітного поля Землі (ПІЕМПЗ) у задачах площинного прогнозування деформації земної поверхні, для оцінювання карстопровальної небезпеки в межах територій відпрацьованих соляних родовиш.

Методика. Опрацювання за допомогою ГІС-технологій інформації, отриманої в результаті вимірів ПІЕМПЗ. Просторове суміщення результатів інтерпретації даних вимірів, отриманих методом ПІЕМПЗ, із результатами геодезичних спостережень.

Результати. Побудоване зображення просторового сумішення карт інтенсивності ПІЕМПЗ і просідань земної поверхні. Доведена гіпотеза про те, що аномалії ПІ- 
ЕМПЗ є безпосереднім індикатором зміщень земної поверхні.

Наукова новизна. Уперше на прикладі території Стебницького родовища калійної солі виконане співставлення результатів даних топогеофізичної зйомки й геофізичного методу ПІЕМПЗ. Доведена відповідність геодезичних і геофізичних даних і суттєвий рівень їх кореляції. Зазначене дає підстави розглядати метод ПІЕМПЗ як прогнозний у частині передбачення зон поширення деформаційних процесів земної поверхні та їх активізації.

Практична значимість. Запропоновано удосконалення методики інтерпретації даних ПІЕМПЗ шляхом залучення геодезичної інформації.

Ключові слова: просідання, провали, геофізичні дослідження, карст, соляне родовище, зміщення

\section{Проседания и провалы на территории соляных месторождений Прикарпатья и возможность их прогнозирования}

\section{Е. Д. Кузьменко, И. В. Чепурный, Т. Б. Чепурна, С.М. Багрий}

Ивано-Франковский национальный технический университет нефти и газа, г. Ивано-Франковск, Украина, email: tetti.chepurna@gmail.com

Цель. Показать эффективность применения метода измерений естественного импульсного электромагнитного поля Земли (ЕИЭМПЗ) в задачах плоскостного прогнозирования деформации земной поверхности, для оценки карстопровальной опасности в пределах территорий отработанных соляных месторождений.

Методика. Обработка с помощью ГИС-технологий информации, полученной в результате измерений ЕИЭМПЗ. Пространственное совмещение результатов интерпретации данных измерений, полученных методом ЕИЭМПЗ, с результатам геодезических наблюдений.

Результаты. Построено изображение пространственного совмещения карт интенсивности ЕИЭМПЗ и просадок земной поверхности. Доказана гипотеза о том, что аномалии ЕИЭМПЗ являются непосредственным индикатором смещений земной поверхности.

Научная новизна. Впервые на примере территории Стебницкого месторождения калийной соли выполнено сопоставление результатов данных топогеофизической съемки и геофизического метода ЕИЭМПЗ. Доказано соответствие геодезических и геофизических данных и существенный уровень их корреляции. Указанное дает основание рассматривать метод ЕИЭМПЗ как прогнозный в части предсказания зон распространения деформационных процессов земной поверхности и их активизации.

Практическая значимость. Предложено усовершенствование методики интерпретации данных ЕИЭМПЗ путем привлечения геодезической информации.

Ключевые слова: просадки, провалы, геофизические исследования, карст, соляное месторождение, смещения

Recommended for publication by V.R. Khomin, Doctor of Geological Sciences. The manuscript was submitted 03.05.19. 